\title{
鼻副鼻腔悪性リンパ腫の臨床的検討
}

\author{
黒田 正人・犬塚 一男・稲福 繁 \\ 石神 寛通・瀧本勲
}

\section{Clinical Study of Malignant Lymphoma of the Nose and Paranasal Sinuses}

\author{
Masato Kuroda, Ichio Inuzuka, Shigeru Inafuku, \\ Hiromichi Ishigami and Isao Takimoto \\ (Aichi Medical University)
}

We encountered 15 cases of malignant lymphoma of the nose and paranasal sinuses during the past 15 years.

Malignant lymphoma of the nose and paranasal sinuses most frequently occurs in patients between 40 and 70 years of age. However, this disease has also been noted in younger patients.

As there are no specific clinical symptoms, it is generally difficult to diagnose this type of malignant lymphoma during the early stage.

Histological diagnosis of malignant lymphoma is frequently impossible even after several biopsies of the tissue. The timing for early treatment is therefore very important.

In starting treatment after a definite diagnosis has been made, it is necessary to determine the precise stage of the disease as well as the sites of all lesions to predict progression of the tumor.

Against localized malignant lymphoma of the nose and paranasal sinuses, radiotherapy in combination with chemotherapy is necessary and surgery is sometimes required.

In conducting chemotherapy, it is necessary to consider the side effects of drugs.

Key words: nose and paranasal sinuses, malignant lymphoma, diagnosis

\section{はじめに}

悪性リンパ腫はリンパ網内系に発生する悪性 腫瘍の総称であり，近年この疾患群の新たな分 類も報告され，更に治療に执いても，放射線療 法, 化学療法剤も急速に進歩し, 寛解率 - 生存 率の著しい改善が認められている.なかでも， 化学療法の進歩は目覚ましいものがあり, CHOP (cyclophosphamide, adriamycin, on- covin, prednisone) 療法を始めとする多剤併用 療法が考案され，優れた成績が得られている. 耳鼻咽喉科領域での悪性リンパ腫の好発部位は, 典型的なりンパ組織を有する頸部リンパ節やワ ルダイェルリングであり, 典型的リンパ組織を 欠く鼻副鼻腔領域に好発する悪性リンパ腫は頻 度が低い，また，病変の進展も限局的傾向を示 すことが多いと考兄られている。しかし，鼻副 
鼻腔原発の悪性リンパ腫は臨床上癌腫との鑑別 診断，扣よび病理組織診断に困難を伴うことが 多く，治療開始が遅れたり或いは悪性リンパ腫 としての適切な治療を行いえぬ症例もまれでな W.

一般に，正確な病期の把握と病理組織的所見 の確診によって，悪性リンパ腫の治療方針は決 定され，それより予後がある程度推測される。

我々の教室で15年間に経験した鼻副鼻腔領域 にみられた悪性リンパ腫15症例について，性別， 発症年齡, 初発部位, 初発症状, 診断時病期, 組織型および $\mathrm{T} \cdot \mathrm{B}$ 分類，更に治療成績を報告 する。

\section{対象亡方法}

1）当大学の耳鼻咽喉科学教室および第一, 第二内科学教室において，昭和 53 年から平成 4 年までの15年間に経験した鼻副鼻腔領域にみら
れた悪性リンパ腫15症例を対象とした(表 1 ).

2 ) 悪性リンパ腫の組織型は LSG 分類(表 $2 \mathrm{~A}$ )に, 病期の決定はAnn Arbor の分類(表 3 )に従った。 また，検査としては腫瘍シンチ グラム, 肝脾シンチグラム, リンパ管造影, CTスキャン，腹部エコーなどを施行した。

\section{結果}

1）性別および年齢

図 1 のごとく，性別は男性 9 例 $(60 \%)$ ，女性 6 例 (40\%)で男性に多い傾向を示した。年龄分 布は 3 歳〜80歳にわたり，10歳以下 1 例 $(6.7$ $\%) ， 20$ 歳代 1 例 $(6.7 \%) ， 30$ 歳代 2 例 (13.3\%), 40 歳代 3 例 (20\%)，50歳代 2 例 $(13.3 \%) ， 70$ 歳 代 5 例 $(33.3 \%) ， 80$ 歳以上 1 例 $(6.7 \%)$ と70歳 代に多く平均 53.5 歳であった。

\section{2）初発症状}

初発症状は，鼻閉，鼻出血，覀臭鼻漏が多く，

表 1 鼻副鼻腔悪性リンパ腫15症例

\begin{tabular}{|c|c|c|c|c|c|c|c|c|c|}
\hline 症例 & 年龄 & 性別 & 組絴型 & TB細胞分類 & 病期 & 初発部位 & 治 & 経過 & 転熳 \\
\hline 1 & 38 & 男 & diffuse medium & 不明 & I E & 右賞腔 & $\begin{array}{l}\text { R(4140R), Caldwell Luc } \\
\mathrm{C}(\mathrm{CQ}, \mathrm{CPM}, \mathrm{PDN})\end{array}$ & 1 年 & 死亡 \\
\hline 2 & 48 & 男 & diffuse medium & 判定不能 & I E & 両血腔 & $\begin{array}{l}\mathrm{R}(5040 \mathrm{R}) \\
\mathrm{C}(\mathrm{COP}, \mathrm{BEMP})\end{array}$ & 2 力月 & 死亡 \\
\hline 3 & 57 & 男 & diffuse large & 不明 & IV & 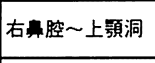 & $\begin{array}{l}R(3960 R), \text { Caldwell Luc } \\
C(\text { COPP })\end{array}$ & 2 年1力月 & 死亡 \\
\hline 4 & 74 & 男 & diffuse small & 不明 & IV & 右腔 & $\begin{array}{l}\mathrm{R}(1980 \mathrm{R}) \\
\mathrm{C}(\mathrm{CHOP})\end{array}$ & 2 力 & 死亡 \\
\hline 5 & 46 & 女 & diffuse large & $B$ cell & I E & 左腔 & $\begin{array}{l}\mathrm{R}(50 \mathrm{G} y)(40 G y), \text { Denker } \\
\mathrm{C}(\mathrm{CHOP}, \mathrm{CVP})\end{array}$ & 7年6力月 & 生存 \\
\hline 6 & 80 & 男 & diffuse medium & $B$ cell & I E & 右腔 & $\mathrm{C}(\mathrm{CHOP})$ & 4 年6力月 & 生存 \\
\hline 7 & 3 & 男 & Burkitt & 不明 & II E & 右腔～上影洞 & \begin{tabular}{|l|} 
上頻洞試験開放 \\
C(VCR, CPM, ADR, MTX, AraC, 6MP, PDN) \\
\end{tabular} & 6年5 月月 & 生存 \\
\hline 8 & 72 & 女 & diffuse medium & 不明 & I E & 左腔 & $\begin{array}{l}\mathrm{R}(50 \mathrm{~Gy}), \text { Caldwell Luc } \\
\mathrm{C}(\mathrm{CHOP})\end{array}$ & 10 力月 & 死亡 \\
\hline 9 & 25 & 女 & diffuse mixed & T cell & I E & 右望腔 & $\begin{array}{l}\mathrm{R}(48 \mathrm{~Gy}), \text { Denker } \\
\mathrm{C}(\mathrm{CHOP})\end{array}$ & 5 年3カ月 & 死亡 \\
\hline 10 & 52 & 男 & 分類不能 & 不明 & I E & 右腔 & $\begin{array}{l}\mathrm{R}(5040 \mathrm{R} \text { 上頻, 5000R 頻下部) } \\
\mathrm{C}(\mathrm{COP}), \text { Caldwell Luc }\end{array}$ & 1 年 2 力 & 死亡 \\
\hline 11 & 71 & 女 & diffuse mixed & 不明 & I E & 左䞏腔 & $\begin{array}{l}\text { R(50Gy), Caldwell Luc } \\
\text { C(CHOP) }\end{array}$ & 1 年 4 力月 & 生存 \\
\hline 12 & 74 & 女 & diffuse medium & 不明 & I E & 左管骨洞 & $\begin{array}{l}\mathrm{R}(60 \mathrm{~Gy}) \\
\mathrm{C}(\mathrm{CHOP})\end{array}$ & 3 年2力月 & 生存 \\
\hline 13 & 74 & 男 & diffuse medium & 不明 & III E & 右腔～前頭洞 & $\begin{array}{l}R(50 G y) \\
C(C H O P)\end{array}$ & 4年2力月 & 生存 \\
\hline 14 & 49 & 男 & diffuse large & 不明 & I E & 右济腔 & $\begin{array}{l}\mathrm{R}(50 \mathrm{~Gy}), \text { Caldwell Luc } \\
\mathrm{C}(\text { COPP) }\end{array}$ & 3年1 カ月 & 生存 \\
\hline 15 & 39 & 女 & diffuse medium & T cell & I E & 右腔～上頻洞 & $\begin{array}{l}R(50 G y) \\
C(\text { COPP })\end{array}$ & 10 力月 & 死亡 \\
\hline
\end{tabular}

$\mathrm{R}$ : irradiation, $\mathrm{C}$ : chemotherapy, $\mathrm{CQ}$ : carbazil quinone, $\mathrm{CPM}$ : cyclophosphamide, PDN: prednisone

COP: cyclophosphamide, oncovin, prednisone, BEMP: bleomycin, endoxan, 6-mercaptopurine, prednisone

COPP: cyclophosphamide, oncovin, procarbazine, prednisone, CHOP: cyclophosphamide, adriamycin, oncovin, prednisone, CVP: cyclophosphamide, vincristine, prednisone, VCR: vincristine, ADR: adriamycin, MTX: methotrexate, AraC: cytosine arabinoside, 6MP: 6-mercaptopurine 


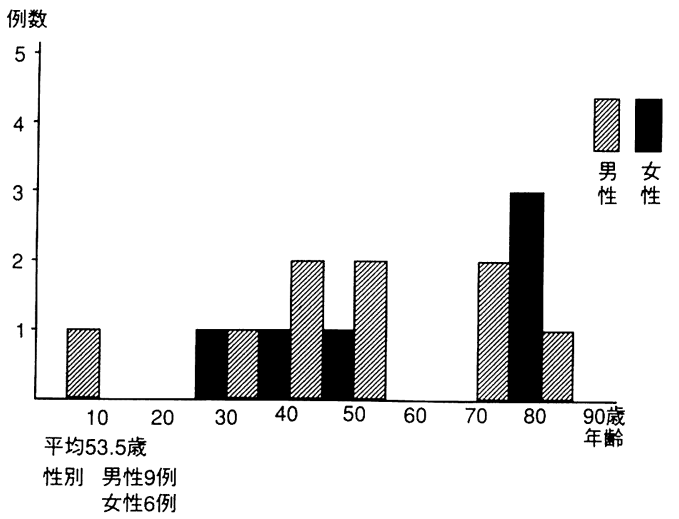

図 1 性別および年齢
表 3 LSG 分類と TB 分類

\begin{tabular}{l|cc}
\hline \hline diffuse(LSG) & \multicolumn{2}{|c}{ 症 例 数 } \\
\hline small type & 1 例 & $(6.7 \%)$ \\
medium type & 7 例 & $(46.7 \%)$ \\
mixed type & 2 例 & $(13.3 \%)$ \\
large type & 3 例 & $(20.0 \%)$ \\
Burkitt type & 1 例 & $(6.7 \%)$ \\
分類不能 & 1 例 & $(6.7 \%)$
\end{tabular}

\begin{tabular}{|c|c|}
\hline TB 分類 & 症 例 数 \\
\hline T cell & 2例 $\quad(13.3 \%)$ \\
\hline$B$ cell & 2例 $\quad(13.3 \%)$ \\
\hline 判定不能 & 1例 $\quad(6.7 \%)$ \\
\hline 不明 & 10例 $(66.7 \%)$ \\
\hline
\end{tabular}

表 2 A Ann Arbor 病期分類

\begin{tabular}{|c|c|}
\hline \multirow[t]{2}{*}{ I 期 } & I ：1つのリンパ節領域 \\
\hline & 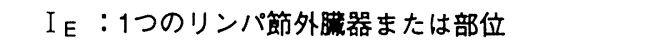 \\
\hline \multirow[t]{2}{*}{ II 期 } & $\begin{array}{c}\text { II : 横隔膜の上下いずれか一方における2つ以上 } \\
\text { のリンバ節領域 }\end{array}$ \\
\hline & $\begin{aligned} \mathbb{I}_{\mathrm{E}}: & : 1 つ \text { 限局性リンパ節外䑏器または部位 } \\
& \text { と横隔膜の上下いずれか1つにおける1つ } \\
& \text { 以上のリンバ節領域 }\end{aligned}$ \\
\hline \multirow[t]{3}{*}{ 向期 } & 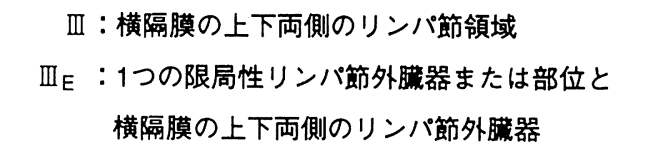 \\
\hline & 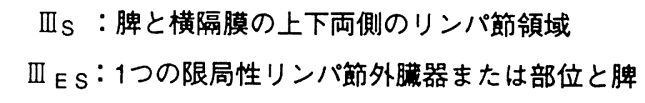 \\
\hline & と横隔膜の上下両側のリンパ節領域 \\
\hline IV 期 & $\begin{array}{l}\text { 関連リンパ節領域侵襲の有無にかかわらず、1つ以上 } \\
\text { のリンパ節外臟器または部位のびまん性侵潤 }\end{array}$ \\
\hline
\end{tabular}

表 2 B 診断時病期

\begin{tabular}{c|c}
\hline \hline 病 期 & 症例数 \\
\hline$I_{E}$ & 11例 $(73.3 \%)$ \\
\hline$I_{E}$ & 1例 $(6.7 \%)$ \\
\hline$I_{E}$ & 1例 $(6.7 \%)$ \\
\hline$I V$ & 2例 $(13.3 \%)$
\end{tabular}


その他視力障害, 眼球突出, 眼瞼腫脹, 耳閉感 などがみられた。しかし，局所症状の特異性に は乏しかった。

\section{3 ）全身症状}

悪性リンパ腫にしばしば認められる体重減少, 発熱, 易疲労性などの全身症状は, 病期が I III期の症例には認められなく, $\mathbb{N}$ 期の一部の症 例のみに認められた。

\section{4 ) 診断時病期}

診断時病期は表 $2 \mathrm{~B}$ のごとく， $\mathrm{I}_{\mathrm{E}}$ 期 11 例 (73.3\%)， $\Pi_{\mathrm{E}}$ 期 1 例 (6.7\%)， $\mathrm{II}_{\mathrm{E}}$ 期 1 例 $(6.7$ $\%), \mathrm{N}$ 期 2 例 (13.3\%) で $\mathrm{I}_{\mathrm{E}}$ 期が大部分であ った。すなわち鼻副鼻腔領域の悪性リンパ腫は 限局的傾向を示すと考えられる.

\section{5 ) 組織診断}

初診から組織診断のつくまでを検討してみる と, 初回の組織診で診断のついた例は 9 例, 3 例は 2 回目, 2 例は 3 回目で, 他 1 例は 6 回目 の組織診だった。平均すると15.5 10.3 (平均 值士標準偏差) 日かかった．腫瘤を形成する型 は比較的容易であるが，壊死を伴ってくる型は なかなかむずかしかった。

また, 組織型は表 3 のごとく，いずれも diffuse type で small cell 1 例 $(6.7 \%)$, medium cell 7 例 (46.7\%), mixed cell 2 例(13.3\%), large cell 3 例(20.0\%), Burkitt type 1 例(6.7 $\%$ ，分類不能 1 例 (6.7\%) で medium cell type が多かった． T・B 細胞分類は， T 細胞型 2 例 (13.3\%), B 細胞型 2 例 (13.3\%) 判定不能 1 例(6.7\%), 不明10例(66.7\%)であった。

6 ）治療成績

治療は内科扣よび小児科と協同で行った。治 療法としては表 4 亿示すごとく, 試験開洞も含
めた手術療法, 化学療法, 放射線療法の 3 者併 用療法をとった例が 8 例 (Caldwell Luc 6 例, Denker 2 例)，手術療法と化学療法をとった 例が 1 例 (上頸洞試験開放), 放射線療法と化学 療法をとった例が 5 例, 化学療法単独が 1 例で あった．手術療法を先行した 6 例の内訳は，確 定診断を得る目的のものが 3 例，根治的手術目 的のものが 3 例であった．他 3 例は化学療法, 放射線療法後根治的手術の目的で施行した．放 射線療法を先行, 続いて化学療法を施行したも の 5 例, 化学療法を先行させた例は 4 例であっ た。

生存率をみると全体で 5 年生存率 $20 \%$ で予後 は極めて悪い結果であった。

病期別に 3 年生存率， 5 年生存率をみると表 5 のごとく $\mathrm{I}_{\mathrm{E}}$ 期 $45.5 \%, 18.2 \%, \mathrm{I}_{\mathrm{E}}$ 期 $100 \%$, $100 \% ， \mathbb{I}_{\mathrm{E}}$ 期 $100 \% ， 0 \% ， \mathbb{N}$ 期 $0 \% ， 0 \%$ で あった。これは症例数が少ないので確定は出来 ないが， I $\mathrm{E}$ 期であっても必ずしも予後は良く ないことを示していると思われる。また逆に， 鼻副鼻腔領域の悪性リンパ腫に対してはAnn Arbor の病期分類が必ずしも予後と一致しない ともいえる。

治療法別に 3 年生存率， 5 年生存率をみると 手術療法, 放射線療法, 化学療法の 3 者併用療 法では $37.5 \%, 12.5 \%$, 手術療法と化学療法の 併用療法では $100 \% ， 100 \%$, 放射線療法と化学 療法の併用療法では $40 \%, 0 \%$, 化学療法単独 では $100 \% ， 0 \%$ である゙，症例数が少ないの で一定の傾向は認められなかった。

死因別に検討してみると，肺炎を併発したも の 3 例，中枢神経系に浸潤したもの 3 例，全身 に播種したもの 2 例である．中枢神経系への浸

表 4 治療法

\begin{tabular}{l|l}
\hline \hline 手術療法十化学療法十放射線療法 & 8例 ( IE 7, IV1) \\
\hline 手術療法十化学療法 & 1例 (IE 1) \\
\hline 放射線療法十化学療法 & 5 例 ( IE 3, IIE1, N 1) \\
\hline 化学療法 & 1例 ( IE 1)
\end{tabular}


潤症例では，いずれも手足のしびれ感から始ま っており，当初ビンクリスチンの副作用とも考 えられたが，後日髄液検査で腫瘍細胞が出現し 判明した. 鼻副鼻腔領域の悪性リンパ腫はとか く同領域に限局するものと考光がちであるが， 悪性リンパ腫の全身播種傾向の強いことを考え ると，た党ず臨床症状および所見のチェックが 必要と思われた。

\section{考案}

\section{1. 発生頻度}

耳鼻咽喉科領域における悪性リンパ腫の内鼻 副鼻腔に発症する頻度に関しては，小田ら ${ }^{1)}$ お よび浅野ら2)の報告がある。少田ら ${ }^{11}$ は耳鼻咽 喉科領域の悪性リンパ腫37症例中，ワルダイェ ルリングが 30 症例で最も多く, 頸部リンパ節 2 症例, 鼻副鼻腔に 2 症例を認めている。そして 頸部リンパ節に頻度が少なかったのは，我国に おいてはこの部位は外科を受診するためであろ らと報告している。 このようにワルダイエルリ ングからの発生が多くを占めているのに対して， 鼻副鼻腔よりの発生率は低く, 浅野ら ${ }^{2)}$ は昭和 32 年から 47 年までの 15 年間で悪性リンパ腫の総 数82症例中, 鼻副鼻腔領域のものは15症例で約 $18 \%$ としている。松本ら ${ }^{3)}$ は $12.5 \%$, Robert

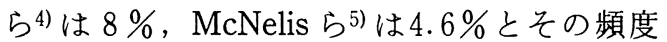
もさまざまである. 当教室においては昭和 53 年
より平成 4 年までの 15 年間で, 悪性リンパ腫を 部位別にみると，ワルダイェルリング33症例， 鼻副鼻腔15症例, 口蓋 5 症例, 中咽頭 6 症例, 頸部リンパ節12症例, その他10症例, 従って総 数 81 症例中, 鼻副鼻腔悪性リンパ腫は約 $18 \%$ と なり諸家の報告に比し，やや高率に出現してい る。

2. 性別および年路分布

鼻副鼻腔領域の悪性リンパ腫15例の性別発症 頻度は男性 $60 \%$ ，女性40\%で男性が多かった。 これは諸家の報告6)7)でも 2 3:1 で男性に多 いのと一致している。また年齢分布は40歳代, 50歳代，70歳代に多かった。これは諸家の報 告8) 10) でも好発年齢は50～60歳代であると されており，この傾向は40～50歳より急に増加 する厚生省人口動態統計との報告と一致してい る。このように高齢者に好発する点では，癌腫 の年齢と重複するのでその鑑別を要する．しか し，悪性リンパ腫は 20 歳代が $6.7 \% ， 30$ 歳代が $13.3 \%$ と若年層にも発症しておう，この点では 癌腫とやや異なる.

\section{3 . 臨床診断}

鼻副鼻腔領域の悪性リンパ腫は限局型が多く, 比較的長く局所にとどまり，特異的熱型，夜間 盗汗，体重減少など全身症状が早期には出現し にくいこと, また鼻閉, 頓部腫脹を初発症状と

表 5 治療成績

\begin{tabular}{c|c|c|c|c}
\hline \hline 病 期 & IE & IIE & IIE & IV \\
\hline $\begin{array}{c}\text { 3年生存率 } \\
(\%)\end{array}$ & 45.5 & 100 & 100 & 0 \\
\hline $\begin{array}{c}5 \text { 年生存率 } \\
(\%)\end{array}$ & 18.2 & 100 & 0 & 0
\end{tabular}

\begin{tabular}{|c|c|c|c|c|}
\hline 治 療 法 & $\begin{array}{c}\text { 手術、放射線 } \\
\text { 化 学 }\end{array}$ & $\begin{array}{l}\text { 手 術 } \\
\text { 化 学 }\end{array}$ & $\begin{array}{l}\text { 放射線 } \\
\text { 化 学 }\end{array}$ & 化 学 \\
\hline $\begin{array}{c}\text { 3年生存率 } \\
(\%)\end{array}$ & 37.5 & 100 & 40 & 100 \\
\hline $\begin{array}{c}\text { 5年生存率 } \\
(\%)\end{array}$ & 12.5 & 100 & 0 & 0 \\
\hline
\end{tabular}


するものが多く4)，局所症状の特異性に乏しい ことから，早期診断がむずかしい，我々の症例 でも， $\mathrm{I}_{\mathrm{E}}$ 期が 15 例中11例と大部分を占めてい た. 局所症状は鼻閉, 鼻出血が多く，これらは 日常診療に扣いても，しばしば認められるため 注意を要する．全身症状では特異的熱型を示す ものはなく, 夜間盗汗, 体重減少が病期が $\mathrm{N}$ 期 の一部の症例に認められたのみであった。よっ て, 全身症状が存在する場合, 病変が全身に進 行していると考えられる.

\section{4. 病理組織学的診断}

治療方針決定の為に，悪性リンパ腫とその他 の腫瘍との鑑別, 特に病理組織学的な診断が早 急に必要であるが，悪性リンパ腫の場合には， 再三の生検を行っても確定診断を得られないこ とが少なくない，我々の15例では初回の生検で 確定診断がついたのは60\%であったが， 2 例は 3 回目, 1 例は 6 回目だった. Birt ${ }^{8)}$ も鼻副鼻 腔覀性リンパ腫例のうち初回生検にて診断され たのは半数以下であったと報告しており，病理 組織学的確定診断の難しさがうかがわれる. 浅 野ら ${ }^{2)}$ は15例の鼻副鼻腔悪性リンパ腫のうち11 例は確定診断を得たが，4例は疑いにとどまっ たとしており，特に鼻腔例では，鼻壊疽との鑑 別が必要な為に更に病理診断上困難な条件が加 わってくると述べている.

治療方針決定の為に, 病理組織学的な診断が 早急に必要であるが，以上述べた如く悪性リン パ腫の組織診断は再三の生検によっても確定診 断が得られないことが少なくないので，早期治 療の時期を失わない事が重要である. 組織型は LSG 分類の 5 種類が認められた。比較的予後 が良い medium type が多かった。

日本では九州地方に $\mathrm{T}$ 細胞型が多く，中部地 方を境にして東北・北海道ではB 細胞型が多い と言われているが，我々の症例では末施行例が 多いが， B 細胞型， $\mathrm{T}$ 細胞型共に同様な比率で 認められた。この場合, $\mathrm{T}$ 細胞型, B細胞型と も，ある特定の cell markerのみが，特異的に 増加するのではなく，リンパ球系としては同系
であるが，他の cell marker も少なからず増加 する．これは腫瘍が単一の細胞より発症してい ないと考えるか，単なる非特異的反応と考劣る か，興味ある問題である。

5 . 治 療

一般に悪性リンパ腫は放射線療法にも化学療 法にもよく反応を示し，現在までに多くの方法 が考光られてきた．今後治療を始める際にはそ れぞれの方法の特徴をいかした計画的な方針を 立てることが重要である.

治療開始に当たり, 確定診断後の正確な病期 把握と共に, 全ての病変の存在箇所を確認し, 腫瘍の進展傾向を知ることが必要である. 我々 の症例でも全例に病期把握を行い治療したが， 予後不良の症例も多かった。 これは悪性リンパ 腫の治療のむずかしさをらかがわせる，悪性り ンパ腫の治療方針としては，I，II期に対して は放射線療法を， III， $\mathbb{N}$ 期に対しては化学療法 を主とした方法が従来から採用されてきた。 た，手術療法は一般に悪性リンパ腫は系統的疾 患であるとの考えよりむしろ禁忌とされていた。 しかし，Diamond ${ }^{11)}$ は局所に限局し全身症状 のないI 型には手術放射線療法が適応となると 述べている. 入江ら ${ }^{12)}$ は I 期では手術施行後 放射線治療群 7 症例で 2 年生存率 $100 \%$, 手術 非施行放射線治療群 13 症例で 2 年生存率 $63.6 \%$ と報告している。これらの報告をみても局所に 限局している時には手術療法は禁忌とは言い難 いことを示している．我々の症例では I 期では 手術施行群 7 症例で 3 年生存率 $42.9 \%$, 手術非 施行群 4 症例で 3 年生存率 $50 \%$ と治療成績は洼 ぼ同様であった。限局型が多い鼻副鼻腔原発例 は適切な局所放射線療法により良好な成績を上 げている13114) 場合が多い。しかしながら最近， 限局的傾向の症例に対する化学療法の必要性が 重視されてきた。浦谷ら13)によれば，悪性り ンパ腫の再発例では，被照射野の局所再発は例 外的で, 再発の多くはそれ以外の臓器からであ る点, また本腫瘍の蔓延形式自体が，単中心性 とは断言できない点より， II期に対する化学療 
法併用の必要性を指摘している。Podoshin ら15) も上顎洞の non-Hodgkin リンパ腫で照射 と多剂併用療法とにより寛解に成功し，その有 効性を認めている. 我々の症例でも $\mathrm{I}_{\mathrm{E}}$ 期で放 射線療法施行し，これにより腫瘍は著明に縮小 する場合が多いが，これらの症例にも全て化学 療法を併用している。しかし，化学療法を行う 場合は薬剤の副作用に最大の注意を払ら必要が ある.すなわち，使用する薬剤はいずれも生体 に重大な障害を及ぼすからである。しかも，同 じ薬剤にしても，各々の生体の感受性が異なり, しばしば致命的な結果となることがある。最も 注意すべき副作用は白血球の減少であろう，鼻 副鼻腔といら特殊な部位から発生した悪性リン 八゚腫の限局例に対しても化学療法併用は必要と 思われるが，副作用には注意を払うべきである。

\section{まとめ}

鼻副鼻腔原発の悪性リンパ腫15症例について 検討した。

1 . 鼻副鼻腔悪性リンパ腫の好発年齢は40～ 70歳代である。しかし，若年層にも発症してい る.

2. 臨床症状は特異性に乏しく，一般に悪性 リンパ盾としての早期診断が困難なことが多い，

3 . 悪性リンパ腫の組織診断は再三の生検に よっても確定診断が得られないことが少なくな いので，深部から大きく取るなど努力をして早 期治療の時期を失わない事が重要である.

4. 治療開始に当たり, 確定診断後の正確な 病期把握と共に，全ての病変の存在箇所を確認 し，腫瘍の進展傾向を知ることが必要である.

5. 鼻副鼻腔悪性リンパ腫の限局例に対して, 放射線療法のみならず化学療法併用は必要であ り，症例により手術療法も行らべきである。

6. 化学療法を行う場合には薬剤の副作用に 注意を払う必要がある。

\section{謝 辞}

稿を終えるにあたり，終始御助言をいただいた当 大学第二内科学大圓修身講師に深く感謝いたします。

\section{参考文献}

1）小田雅義, 西村武重, 斉藤 等, 他: 耳鼻咽喉 科領域に打ける肉腫について。耳鼻臨床 59 ： 638〜947, 1966.

2) 浅野 登, 斉藤 等, 松岡秀樹, 他: 鼻副鼻腔 悪性リンパ腫の教室集計より見た治療方針.耳 鼻臨床 $65: 1243 \sim 1255,1972$.

3）松本明, 牧本一男, 宇野良二, 他: 細網肉腫 の剖検例飞関する統計的観察.耳鼻臨床 $56: 33$, 1963.

4) Robert A and Charles W : Malignant lymphoma of the paranasal sinuses. Arch Otolaryngol $101: 287 \sim 292,1975$.

5) McNelis FL and Pai VT : Malignant lymphoma of head and neck. Laryngoscope 79 : 1076 1087, 1969.

6）橋口哲美, 村上嘉彦, 中原千恵子, 他: 副鼻腔 肉腫 2 症例とその文献的考察. 耳喉 12:1017 $\sim 1027,1970$.

7）谷本一夫：わが国における悪性リンパ腫の疫学. 内科 $41: 364 \sim 368,1971$.

8) Birt BD : Reticulum cell sarcoma of the nose and paranasal sinues. J Laryng Otol 84 : 615 625, 1970.

9) Gottlieb JA : Lymphsarcoma of the paranasal sinuses. Arch Otolaryng 93 : 199 202, 1971.

10）浜口幸吉, 坂倉康夫, 鵜飼幸太郎, 他 : 鼻副鼻 腔悪性リンパ腫 7 症例の検討. 耳鼻臨床 73 ： $1447 \sim 1456,1980$.

11) Diamond HD : Clinical Indications for the use of nitrogen mustard and triethylene melamine in malignant lymphomas and leukemias. Ann New York Acad Sci 68 : 974 978, 1958.

12）入江英雄, 村上晃一, 前田辰夫, 他 : 悪性リン 分腫の放射線治療成績。日本医放会誌 28 : 1232 1233, 1968.

13）浦谷忠雄，小林仁和，清水友収，他：細網肉腫 の治療成績. 耳喉 $50: 29 \sim 33,1978$.

14) Lehrer $S$ and Roswit $B$ : Primary malignant lymphoma of the paranasal sinuses. Ann Otol Rhinol Laryngol $87: 81 \sim 84,1978$.

15) Podoshin L, Talmon $Y$ and Fradis $M$ : Malignant lymphoma of the maxillary sinus. $\mathrm{J}$ Laryngol Otol $92: 613 \sim 618,1978$.

$$
\left(\begin{array}{c}
\text { 別刷請求先 : 黒田正人 } \\
\mathbf{\mathbf { T }} 480-11 \text { 愛知県愛知郡長久手町 } \\
\text { 大字岩作字倠又 } 21 \\
\text { 愛知医科大学耳鼻咽喉科学教室 }
\end{array}\right)
$$

